\title{
New Analysis of Clopidogrel Bisulphate in Plavix Tablet and Human Biological Fluids Utilizing Chemically Modified Carbon Paste Sensor
}

Amal Fouad Khorshid*

Department of Pharmaceutical Analytical Chemistry, Faculty of Pharmacy, Nahda University, NUB, New Beni-Sueff, Egypt

\begin{abstract}
The fabrication and the performance response characteristics of a novel sensitive, selective, simple, and rapid sensor for the determination of clopidogrel bisulphate $\left(\mathrm{CLO}-\mathrm{H}_{2} \mathrm{SO}_{4}\right)$ were described. The sensing modified carbon paste sensor comprised of an iron-pair based on clopidogrel with silicotungastate (CLO-ST) where this study included: composition, usable $\mathrm{pH}$ range, response time and temperature. The sensor exhibited a wide linear dynamic concentration ranging from $1.00 \times 10^{-7}-1.00 \times 10^{-2}$ and the usable $\mathrm{pH}$ ranges from 1.2-4.8 with the response time ranging from (5-8 s) which is much faster compared to liquid ISEs with a detection limit equals $0.34 \mathrm{nM}$. The selectivity of the sensor $\left(\mathrm{CLO}-\mathrm{H}_{2} \mathrm{SO}_{4}\right)$ was applied with respect to a many of organic and inorganic cations, amino acids and sugars. The application of the sensor was utilized in bulk powder, Plavix Tablet, human (serum-urine) and monitoring Plavix tablet dissolution rates. The obtained results were statistically analyzed in both accuracy and precision and were compared using the US pharmacopeia method where there is no significant difference was observed.
\end{abstract}

Keywords: Clopidogrel bisulphate $\left(\mathrm{CLO}-\mathrm{H}_{2} \mathrm{SO}_{4}\right)$; Carbon-paste Sensor; Potentiometry; Dissolution rate

\section{Introduction}

Plavix is a trademark prescription medicine used to treat people who have any of the following:

A heart attack, a Stroke or Recent Stroke, Chest Pain due to Heart problems, Poor circulation in their legs (peripheral arterial disease), Acute Coronary Syndrome (ACS), Established Peripheral Arterial Disease. Clopidogrel reduces the risk of heart attack and stroke in people who have cardiovascular disease [1-4]. Clopidogrel reduces the chance of arterial blockage, by inhibiting platelet aggregation, thus preventing heart attacks and strokes. Clopidogrel bisulfate is methyl (+)-(S)-a-(2-chlorophenyl)- 6,7-dihydrothieno[3,2-c]pyridine-5(4H)acetate sulfate (1:1) with molecular formula $\mathrm{C}_{16} \mathrm{H}_{16} \mathrm{ClNO}_{2} \mathrm{~S}_{2} \mathrm{H}_{2} \mathrm{SO}_{4}$ and its molecular mass equals 419.9 as shown in Figure 1.

The literature survey review refers to different analytical methods such as spectrophotometric methods for determination of CLO [59]. Quantitatively kinetic spectrophotometric for CLO, petaxolol and imidril in its dosage form [10]. Other methods included non-enzymatic and enenzymatic chiral inversion of CLO utilizing NMR and HPLC chiral method [11]. The analysis by GC-MS for metabolite carboxylic acid of CLO in serum and plasma [12], reverse phase HPLC with UV detection for estimation of CLO in its dosage form were presented in [13-17], HPTLC [18,19] and HPLC [20-22]. CLO was determined in

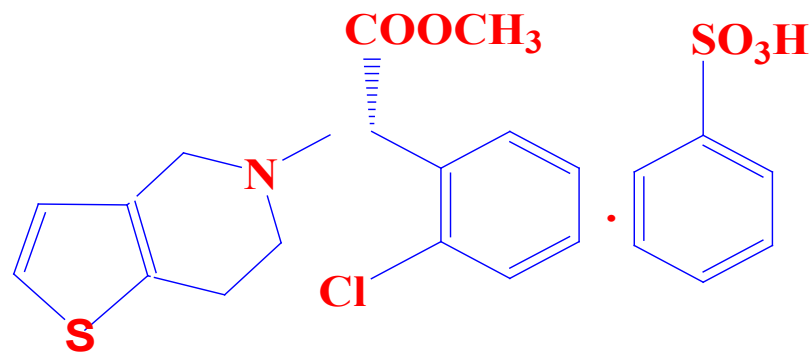

Figure 1: The chemical structure of clopidogrel bisulfate. the presence of its human fluid by mass spectrometry coupled with LC [23,24], and HPLCMS/MS [25]. Also capillary electrophoresis methods were reported [26-28], and voltammetry [29]. No methods are found in the literature for determination of CLO by chemical modified carbon paste (CMCPs)

The electrochemistry and electroanalysis with carbon paste-based sensors is still represents one of the most popular sensor materials with almost unlimited applicability in basic research, highly specialized investigations, as well as in practically oriented electroanalysis [30-32].

This work describes the fabrication, construction with sensor potentiometric characterization, and application of a novel clopidogrelchemically modified carbon paste sensors (CLO-CMCPSs). Using the following ion-pairs; clopidogrel silicotungstate (CLO-ST), clopidogrel silicomolybdate (CLO-SM), clopidogrel phosphotungstate (CLO-PT), clopidogrel phosphomolybdate (CLO-PM), clopidogrel tetraphenylborate (CLO-TPB) and clopidogrel reineckate (CLO-Rein) with solvent mediator 2-Nitrophenyl phenyl ether (2-NPPE) and compared with sensors previously reported [33,34].

\section{Experimental}

\section{Chemicals and materials}

All chemicals used for preparation of solutions were of analytical grade. Doubly distilled water was used throughout all the experiments. Clopidogrel bisulfate and its dosage form (Plavix, $75 \mathrm{mg} /$ tablet) were provided by Sanofi Aventis Company Cairo-A.R.E. Tributyl phthalate

*Corresponding author: Amal Fouad Khorshid, Department of Pharmaceutical Analytical Chemistry, Faculty of Pharmacy, Nahda University, NUB, New BeniSueff, Egypt, Tel: +2/0128-0875558; E-mail: amalkorshid@yahoo.com

Received April 10, 2014; Accepted May 20, 2014; Published May 27, 2014

Citation: Khorshid AF (2014) New Analysis of Clopidogrel Bisulphate in Plavix Tablet and Human Biological Fluids Utilizing Chemically Modified Carbon Paste Sensor. Pharm Anal Acta 5: 301. doi:10.4172/2153-2435.1000301

Copyright: (c) 2014 Khorshid AF. This is an open-access article distributed under the terms of the Creative Commons Attribution License, which permits unrestricted use, distribution, and reproduction in any medium, provided the original author and source are credited. 
(TBP), tricresyl phthalate (TCP), graphite powder, dibutyl phthalate (DBP), dioctyl phthalate (DOP), 2-nitrophenyl phenyl ether (2-NPPE), ammonium reineckate (Amm-Rein), sodium tetraphenylborate (NaTPB), silicotungestic acid (STA), silicomolybdic acid (SMA), phosphomolybdic acid (PMA), and phosphotungestic acid (PTA), were selective products from Aldrich.

$0.5 \mathrm{M}$ chloride solution of each of the following cations: $\mathrm{NH}_{4}^{+}, \mathrm{K}^{+}$, $\mathrm{Na}^{+}, \mathrm{Zn}^{2+}, \mathrm{Ni}^{2+}, \mathrm{Co}^{2+}, \mathrm{Cu}^{2+}, \mathrm{Mg}^{2+}, \mathrm{Ba}^{2+}, \mathrm{Mn}^{2+}, \mathrm{Cr}^{3+}$, and $\mathrm{Fe}^{3+}$ solutions $\left(1000 \mu \mathrm{g} \mathrm{ml}^{-1}\right)$ were obtained from Merck. Glucose anhydrous, lactose monohydrate, maltose, urea, ascorbic acid, aspirin, L-threonine, L-lysine, L-cystine, and L-glycine were obtained from Aldrich. Serum was used within $24 \mathrm{~h}$ and provided by VACSERA (Giza, Egypt) while urine samples were obtained from healthy volunteers. Corn oil, sodium hydroxide and hydrochloric acid are from NODCAR.

\section{The Electrochemical system}

The potentiometric measurements were carried out with a Jenway 3515 digital $\mathrm{pH} / \mathrm{mV}$ meter. A WTW-packed saturated calomel sensor (SCE) was used as an external reference sensor. The electrochemical system was as follows: CMCPS/test solution//SCE. The dissolution profile was studied using USP XXXII [35] method with the paddle apparatus II [36]. The apparatus used for this purpose is model "SR8Plus", CA USA Hanson Research, with number "73-100-116") and the spectrophotometer double beam instrument UV-1800-2011 Shimadzu (Japan).

\section{Sensor preparation}

Chemically modified carbon paste sensors were prepared as previously described [37]. The sensor was used directly for potentiometric measurements without preconditioning requirements. A fresh surface of the paste was obtained by squeezing more out. The surplus paste was wiped out and the freshly exposed surface was polished on a paper until the surface showed shiny appearance.

\section{Construction of the calibration graphs}

Different compositions cover the ranges of $0.5-5 \%$ of CLO were prepared. The measured potential was recorded using the present sensor. Data were plotted as potential versus logarithm of the drug concentration $\mathrm{CLO}^{+}$activity and the calibration graph was used for subsequent determination of unknown drug concentration.

\section{Effect of $\mathbf{p H}$}

The effect of $\mathrm{pH}$ of the test solution on the sensor was investigated by measuring its potential in solutions prepared the concentration range of $1.0 \times 10^{-5}-1.0 \times 10^{-3} \mathrm{M}$ by serial dilution. The sample solution $\mathrm{pH}$ was monitored simultaneously with a conventional glass $\mathrm{pH}$ sensor. The emf readings were taken after the potential reached a constant value. The $\mathrm{mV}$-readings were plotted against the $\mathrm{pH}$-values for the different concentrations.

\section{Effect of temperature on the sensor potential}

The thermal stability of the sensors with calibration graphs were studied covering the range $25-50^{\circ} \mathrm{C}$ of different test solutiontemperatures. The values of $\mathrm{E}^{\circ}$ were plotted versus $(\mathrm{t}-25)$ to the estimation of the thermal coefficients of the sensors. The isothermal coefficient $(\mathrm{dE} / \mathrm{dt})$ of the cell represents the straight line slope obtained by plotting of $\mathrm{E}_{\text {cell }}^{\circ}$ versus ( $\left.\mathrm{t}-25\right)$ and was calculated for each sensor by the following equation (Antropov's equation):

$$
\mathrm{E}_{\text {cell }}^{\mathrm{o}}=\mathrm{E}_{25 \mathrm{C}}^{\mathrm{o}} \mathrm{o}+(\mathrm{dE} / \mathrm{dt})(\mathrm{t}-25)
$$

By the subtraction of the standard sensors potential of the calomel sensor $(241.2,234.4,230.88$ and $223.57 \mathrm{mV})$ at different temperatures $\left(25,35,40\right.$ and $\left.50^{\circ} \mathrm{C}\right)$ so the values of the standard potentials of sensors $\left(\mathrm{E}_{\text {elec. }}^{\circ}\right)$ were calculated.

\section{Sensors selectivity}

The matched potential method (MPM) $[38,39]$ was applied as the previously reported method [37].

The following equation is used to calculate the selectivity values of $\log \mathrm{K}_{\mathrm{CLO}^{\mathrm{p}} \mathrm{J}^{z^{+}}}^{\mathrm{pot}}$

$$
K_{C L O . J^{Z+}}^{\text {POT }}=\frac{\left(a_{A}^{-}-a_{d r u g}\right)}{a_{J}}
$$

Where: $a_{A}^{-}$is the initial concentration of drug, $\mathrm{a}_{\text {drug }}$ is the activity of the added drug and $a_{i}$ is the activity of the added interfering ion producing the same increase in potential.

The separate solutions method (SSM) [40] was applied, to confirm (MPM)

Two potential values were measured for the same concentration of the drug and the interferents. The selectivity values of $\log \mathrm{K}_{\mathrm{CLO}^{\mathrm{p}} \mathrm{J}^{2+}}^{\mathrm{pot}}$ are calculated using the following equation:

$$
\log \mathrm{K}_{\mathrm{CLO}, \mathrm{J}^{2+}}^{\mathrm{pot}}=\frac{\mathrm{E}_{2}-\mathrm{E}_{1}}{\mathrm{~S}}+\log [\mathrm{Drug}]-\log \left[\mathrm{J}^{\mathrm{z+}}\right]^{1 / 2}
$$

Where: $\mathrm{E}_{1}$ and $\mathrm{E}_{2}$ are the sensor potentials of $10^{-3} \mathrm{M}$ solution of each of the CLO drug and interfering cation, $\mathrm{J}^{\mathrm{z}+}$, respectively and $\mathrm{S}$ is the slope of the calibration graph.

\section{Potentiometric determination of CLO}

Small portions $(0.1 \mathrm{ml})$ of standard $10^{-2} \mathrm{M}$ CLO solution were added to $50 \mathrm{ml}$ water-containing different concentrations of drug ranging from $10^{-6}$ to $10^{-4} \mathrm{M}$ or its pharmaceutical dosage form using the following equation:

$$
C_{X}=C_{S}\left(\frac{V_{S}}{V_{X}+V_{S}}\right)\left[10^{n(\Delta E / s)}-\frac{V_{X}}{V_{S}+V_{X}}\right]^{-1}
$$

Where $\mathrm{C}_{\mathrm{x}}$ is the concentration to be determined, $\mathrm{V}_{\mathrm{x}}$ is the volume of the original sample solution, $\mathrm{V}_{\mathrm{s}}$ and $\mathrm{C}_{\mathrm{s}}$ are the volume and concentration of the standard solution added to the sample to be analyzed, respectively, $\Delta \mathrm{E}$ is the change in potential after addition of certain volume of standard solution, and $\mathrm{S}$ is the slope of the calibration graph. Unknown drug concentration was determined from the graph produced by plotting the logarithm of $\mathrm{CLO}^{+}$activity versus the potential.

In the potentiometric titrations different weights ranged from 2.09$41.99 \mathrm{mg}$ of drug was dissolved in $50 \mathrm{ml}$ by bi-distilled water. Different volumes of this solution $(1.0-5.0 \mathrm{~mL})$ were taken and subjected against 0.0025 M STA, 0.0025 SMA, 0.0033 PTA, 0.0033 PMA, 0.01 M (NaTPB and Rein) using the sensor(s). Conventional S-shaped curves with first and second plots were used to determine the end points.

\section{Determination of CLO in plavix}

For sampling of tablets, five Plavix tablets $(75 \mathrm{mg} / \mathrm{tablet})$ were powdered together to fine powder. An accurately weighed portion was taken from this powder, was added to $50 \mathrm{ml}$ bidistilled water and the solution was completed to the mark with bidistilled water then shaken. 
The standard additions technique was applied for the potentiometric determination.

\section{Content uniformity assay of Plavix tablets $<905>$}

One tablet of Plavix (75 mg/tablet) was immersed in the measuring flask and adjusted to $\mathrm{pH} 1$, for measuring each sensor was immediately putted in the sample solution three times and then washed between each individual measurement with distilled water to reach steady potential. The content uniformity was evaluated from the calibration graph by using the mean potential. For the spectrophotometric measurements by employing UV absorbance $\lambda \max 240 \mathrm{~nm}$ with the standard solution [36].

\section{Determination of CLO in biological fluids}

A. In serum: One $\mathrm{mL}$ of standard drug solution from $1 \times 10^{-3}$, $1 \times 10^{-4}$ and $1 \times 10^{-5} \mathrm{M}$ were added into a three of centrifugation $20-\mathrm{ml}$ stoppered shaking tubes [34]. Each tube containing $9 \mathrm{ml}$ of serum and $0.1 \mathrm{~N}$ acetate buffers was added to serum solution dropwise until the suitable $\mathrm{pH}$ obtained. The tubes were shaken well for $1 \mathrm{~min}$ and 10.0 $\mathrm{mL}$ of diethyl ether was added to each tube and centrifuged for $2 \mathrm{~min}$ at $1500 \mathrm{rpm}$. Then, the deproteinated layer was transferred to a $100-\mathrm{mL}$ measuring flask and complete to volume using bidistilled water. The modified sensor was immersed in conjunction with the reference sensor in these solutions and then washed with water between measurements. The emf produced for each solution was measured by the proposed sensor, and the concentration of $\mathrm{CLO}-\mathrm{H}_{2} \mathrm{SO}_{4}$ was determined from the corresponding sensor calibration and standard addition methods.

B. In spiked urine: For urine analysis, different quantities of the drug and $5 \mathrm{ml}$ urine were transferred to a $100 \mathrm{ml}$ volumetric flask and left stirred for $5 \mathrm{~min}$, completed to the mark with doubly bidistilled water and a small volume $(0.1-2.0 \mathrm{ml}) 0.01 \mathrm{M} \mathrm{HCl}$ was added to give solutions of $\mathrm{pH}$ ranging from 4 to 5 and concentrations from $1.0 \times 10^{-6}$ to $5.0 \times 10^{-4}$ $\mathrm{M}$ drug. These solutions were subjected to the standard addition method for drug determination.

\section{Dissolution $<711>$}

One tablet of Plavix (75 mg/tablet) was placed in the vessel of instrument apparatus II. In vitro release study the dissolution medium $(900 \mathrm{ml}$ of $0.01 \mathrm{M} \mathrm{HCl}) \mathrm{pH} 1.2$ was maintained at $37 \pm 0.5^{\circ} \mathrm{C}$ for 2 h. The clopidogrel was kept in hard gelatin capsule so the vessel was rotated at $50 \mathrm{rpm}$. At appropriate time intervals, the potential values were recorded using the clopidogrel sensor in conjunction with saturated calomel sensor (SCE) reference sensor and the amount of clopidogrel released was calculated from the calibration graph. For the spectrophotometric measurements, $5.0 \mathrm{ml}$ aliquots of the dissolution solution were withdrawn, filtered, diluted with $0.01 \mathrm{M} \mathrm{HCl}$ and the concentration of samples was analyzed using UV spectrophotometer (1800, Shimadzu, Japan) and the absorbencies were measured at $\lambda$ max $240 \mathrm{~nm}$. A calibration graph was used for drug release calculation [36].

\section{Results and Discussion}

\section{Composition and performance characteristics of CLO sensors}

The paste with no exchangers displayed no measurable response towards clopidogrel $\left(\mathrm{CLO}^{+}\right)$ion. For this purpose, the ion-associates of $\mathrm{CLO}_{4} \mathrm{ST}, \mathrm{CLO}_{4} \mathrm{SM}, \mathrm{CLO}_{3} \mathrm{PT}, \mathrm{CLO}_{3} \mathrm{PM}, \mathrm{CLO}-\mathrm{TPB}$ and CLO-Rein were prepared. The chemical composition of the precipitates was identified and confirmed by elemental analysis $(\mathrm{C}, \mathrm{H}$, and $\mathrm{N})$ at the Microanalysis Center, Cairo University, Egypt. The results are shown in Table 1.

While the investigated as modifiers for carbon paste sensors selective to clopidogrel as shown in Table 2. The influence of the binder type and concentration on the characteristics of the studied sensors was investigated by using six binders with different polarities including 2-NPPE, TCP, DOP DBP, TBP and Corn Oil.

Different binder/graphite $(\mathrm{w} / \mathrm{w})$ ratios were studied. The sensor with 2-NPPE as a solvent mediator produced the best response, as shown in Figure 2, likely due to better dielectric characteristics of 2-NPPE comparing to other solvents, and the ability of 2-NPPE to extract clopidogrel ions from the aqueous solution to the organic paste phase.

Among the different compositions studied, a paste containing ion-exchanger complex $5.0 \mathrm{wt} \% \mathrm{CLO}_{4} \mathrm{ST}, 54.0 \mathrm{wt} \%$ graphite, and 41.0 wt\% 2-NPPE exhibited the best response characteristics also the lowest detection limit. Therefore, this composition was used to study various operation parameters of the sensor and the optimum composition for the best sensor was given in Table 3. This sensor was chosen in this study and its electrochemical performance characteristics were systematically evaluated according to IUPAC recommendation [40,41].

\section{Reproducibility of the sensor}

The repeatability of the potential reading of the CLO-ST/CMCP sensor was examined by subsequent measurements in $1.0 \times 10^{-3} \mathrm{M}$ CLO$\mathrm{H}_{2} \mathrm{SO}_{4}$ solution immediately after measuring the first set of solution at $1.0 \times 10^{-4} \mathrm{M} \mathrm{CLO}-\mathrm{H}_{2} \mathrm{SO}_{4}$. The standard deviation for 5 replicate measurements of emf was found to be 0.473 in $1 \times 10^{-4} \mathrm{M}$ solution and 0.816 in $1 \times 10^{-3}$ solution.

It was noticed that the slope of the calibration graph obtained by CLO-ST/CMCPS was nearly constant by polishing for any time taken days and then starts to decrease gradually without polishing so it

\begin{tabular}{|c|c|c|c|c|c|c|}
\hline lon-associate & Color & Tentative Formulae & & $\mathbf{C} \%$ & $\mathrm{H} \%$ & N\% \\
\hline \multirow[t]{2}{*}{$\mathrm{CLO}_{4}-\mathrm{ST}$} & (off-white) & {$\left[\mathrm{C}_{16} \mathrm{H}_{16} \mathrm{CINO}_{2} \mathrm{~S}\right]_{4}\left[\mathrm{SiW}_{12} \mathrm{O}_{40}\right]$} & Found & 23.25 & 1.96 & 1.66 \\
\hline & & & (Calc.) & 23.28 & 1.94 & 1.69 \\
\hline \multirow[t]{2}{*}{$\mathrm{CLO}_{4}-\mathrm{SM}$} & (buff) & {$\left[\mathrm{C}_{16} \mathrm{H}_{16} \mathrm{CINO}_{2} \mathrm{~S}\right]_{4}\left[\mathrm{SiMo}_{12} \mathrm{O}_{40}\right]$} & Found & 34.25 & 2.80 & 2.41 \\
\hline & & & (Calc.) & 34.28 & 2.86 & 2.39 \\
\hline \multirow[t]{2}{*}{$\mathrm{CLO}_{3}-\mathrm{PT}$} & (Y. white) & {$\left[\mathrm{C}_{16} \mathrm{H}_{16} \mathrm{ClNO}_{2} \mathrm{~S}\right]_{3}\left[\mathrm{PW}_{12} \mathrm{O}_{40}\right]$} & Found & 17.40 & 1.44 & 1.25 \\
\hline & & & (Calc.) & 17.45 & 1.45 & 1.27 \\
\hline \multirow[t]{2}{*}{$\mathrm{CLO}_{3}-\mathrm{PM}$} & (faint yellow) & {$\left[\mathrm{C}_{16} \mathrm{H}_{16} \mathrm{CINO}_{2} \mathrm{~S}\right]_{3}\left[\mathrm{PMo}_{12} \mathrm{O}_{40}\right]$} & Found & 25.66 & 2.16 & 1.86 \\
\hline & & & (Calc.) & 25.68 & 2.14 & 1.87 \\
\hline \multirow[t]{2}{*}{ CLO-TPB } & (White) & {$\left[\mathrm{C}_{16} \mathrm{H}_{16} \mathrm{CINO}_{2} \mathrm{~S}\right]\left[\mathrm{C}_{24} \mathrm{H}_{20} \mathrm{~B}\right]$} & Found & 64.93 & 4.80 & 1.87 \\
\hline & & & (Calc.) & 64.94 & 4.87 & 1.89 \\
\hline \multirow[t]{2}{*}{ CLO-Rein } & (faint pink) & {$\left[\mathrm{C}_{16} \mathrm{H}_{16} \mathrm{ClNO}_{2} \mathrm{~S}\right]\left[\mathrm{Cr}\left(\mathrm{NH}_{3}\right)_{2}(\mathrm{SCN})_{4}\right]$} & Found & 26.11 & 2.97 & 13.24 \\
\hline & & & (Calc.) & 26.00 & 2.98 & 13.27 \\
\hline
\end{tabular}

Table 1: Elemental analyses of the ion-associates. 
Citation: Khorshid AF (2014) New Analysis of Clopidogrel Bisulphate in Plavix Tablet and Human Biological Fluids Utilizing Chemically Modified Carbon Paste Sensor. Pharm Anal Acta 5: 301. doi:10.4172/2153-2435.1000301

\begin{tabular}{|c|c|c|c|c|}
\hline \multirow[b]{2}{*}{ lon-exchanger } & \multicolumn{4}{|c|}{ Composition \% w/w } \\
\hline & graphite & 2-NPPE & $\begin{array}{c}\text { Slope } \\
\text { (mV/decade) }\end{array}$ & Linear range $(\mathrm{M})$ \\
\hline \multicolumn{5}{|l|}{ CLO4ST } \\
\hline 1.0 & 54.0 & 45.0 & $55.5 \pm 0.5$ & $1.0 \times 10^{-5}-5.0 \times 10^{-3}$ \\
\hline 3.0 & 54.0 & 43.0 & $58.9 \pm 1.0$ & $5.0 \times 10^{-6}-1.0 \times 10^{-2}$ \\
\hline 5.0 & 54.0 & 41.0 & $60.0 \pm 0.5^{*}$ & $1.0 \times 10^{-7}-1.0 \times 10^{-2}$ \\
\hline \multicolumn{5}{|l|}{ CLO4SM } \\
\hline 1.0 & 54.0 & 45.0 & $48.7 \pm 1.5$ & $5.0 \times 10^{-5}-5.0 \times 10^{-3}$ \\
\hline 3.0 & 54.0 & 43.0 & $57.9 \pm 0.5$ & $5.0 \times 10^{-5}-5.0 \times 10^{-3}$ \\
\hline 5.0 & 54.0 & 41.0 & $56.3 \pm 1.5$ & $8.0 \times 10^{-5}-5.0 \times 10^{-3}$ \\
\hline \multicolumn{5}{|l|}{ CLO3PT } \\
\hline 1.0 & 54.0 & 45.0 & $56.7 \pm 1.0$ & $5.0 \times 10^{-5}-1.0 \times 10^{-3}$ \\
\hline 3.0 & 54.0 & 43.0 & $51.5 \pm 1.0$ & $5.0 \times 10^{-6}-5.0 \times 10^{-3}$ \\
\hline 5.0 & 54.0 & 41.0 & $58.5 \pm 0.5$ & $1.0 \times 10^{-6}-1.0 \times 10^{-2}$ \\
\hline \multicolumn{5}{|l|}{ CLO3PM } \\
\hline 1.0 & 54.0 & 45.0 & $53.2 \pm 1.1$ & $5.0 \times 10^{-5}-1.0 \times 10^{-2}$ \\
\hline 3.0 & 54.0 & 43.0 & $56.1 \pm 1.2$ & $5.0 \times 10^{-5}-1.0 \times 10^{-2}$ \\
\hline 5.0 & 54.0 & 41.0 & $56.0 \pm 0.8$ & $5.0 \times 10^{-5}-1.0 \times 10^{-2}$ \\
\hline \multicolumn{5}{|l|}{ CLOTPB } \\
\hline 1.0 & 54.0 & 45.0 & $56.0 \pm 1.7$ & $1.0 \times 10^{-5}-1.0 \times 10^{-2}$ \\
\hline 3.0 & 54.0 & 43.0 & $53.3 \pm 1.1$ & $3.0 \times 10^{-5}-8.0 \times 10^{-3}$ \\
\hline 5.0 & 54.0 & 41.0 & $57.6 \pm 1.5$ & $5.0 \times 10^{-6}-1.0 \times 10^{-2}$ \\
\hline \multicolumn{5}{|l|}{ CLORein } \\
\hline 1.0 & 54.0 & 45.0 & $55.0 \pm 1.7$ & $5.0 \times 10^{-5}-1.0 \times 10^{-2}$ \\
\hline 3.0 & 54.0 & 43.0 & $52.3 \pm 1.1$ & $5.0 \times 10^{-5}-8.0 \times 10^{-3}$ \\
\hline 5.0 & 54.0 & 41.0 & $57.5 \pm 1.5$ & $7.0 \times 10^{-6}-1.0 \times 10^{-2}$ \\
\hline
\end{tabular}

* Selected composition: 5 \%CLO-ST with different plasticizers

\begin{tabular}{|c|c|c|c|c|}
\hline 2-NPPE* & 54.0 & 41.0 & $60.0 \pm 0.5$ & $1.0 \times 10^{-7}-1.0 \times 10^{-2}$ \\
\hline TCP & 54.0 & 41.0 & $58.5 \pm 0.5$ & $5.0 \times 10^{-7}-1.0 \times 10^{-2}$ \\
\hline DOP & 54.0 & 41.0 & $56.8 \pm 0.5$ & $1.0 \times 10^{-6}-5.0 \times 10^{-3}$ \\
\hline DBP & 54.0 & 41.0 & $53.2 \pm 0.5$ & $5.0 \times 10^{-6}-5.0 \times 10^{-3}$ \\
\hline TBP & 54.0 & 41.0 & $52.0 \pm 0.5$ & $1.0 \times 10^{-7}-5.0 \times 10^{-3}$ \\
\hline Corn Oil (Afia) & 54.0 & 41.0 & $57.0 \pm 0.5$ & $5.0 \times 10^{-8}-1.0 \times 10^{-4}$ \\
\hline
\end{tabular}

*Selected Plasticizer

Table 2: Composition and slope of calibration curves for different clopidogrel carbon paste electrodes at $25.0 \pm 0.1^{\circ} \mathrm{C}$.

consider as a new sensor with every one polishing to the sensor. After any period of time a new section from the master paste was found to function very properly.

\section{Dynamic response time}

The dynamic response time [42] of sensor was tested by measuring the time required to achieve a steady-state potential (within $\pm 1 \mathrm{mV}$ ) after successive immersions of the sensor in a series of drug solutions, each having a 10 -fold increase in concentration from $1.0 \times 10^{-7}$ to $1.0 \times 10^{-2}$ $\mathrm{M}$. In this study, practical response time was recorded by increasing CLO concentration by up to 10 -fold. When the sensor was transferred from one concentration solution to another one, it was stabilized to a value higher than its value $(8 \mathrm{~s})$, which may be due to its memory effect. The sensor yielded steady potential within 10-12 s. This is most probably due to the fast exchange kinetics of association-dissociation of clopidogrel ion with the ionophores at the solution-paste interface. The potential-time plot for the response of the sensor CLO-ST is shown in Figure 3.

\section{Effect of $\mathrm{pH}$}

The potential $\mathrm{pH}$ profile obtained indicates that the responses of the sensors are fairly constant over the $\mathrm{pH}$ range $1.2-4.8$ in this range

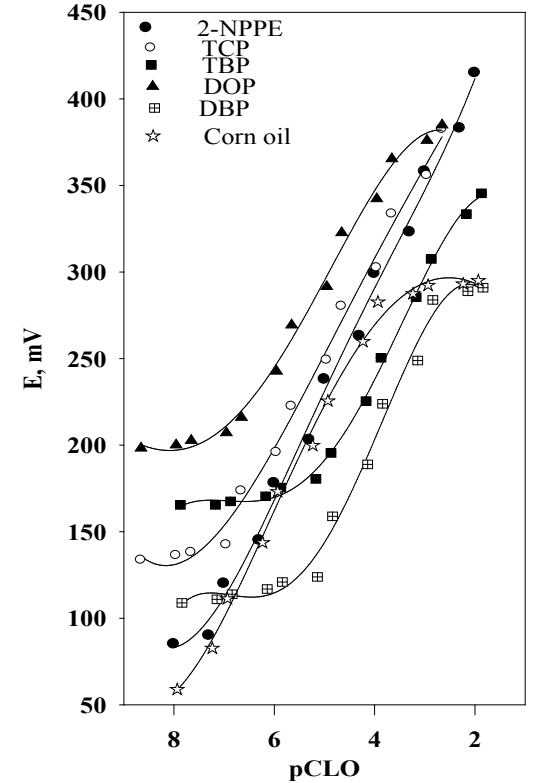

Figure 2: Effect of different plasticizers on the response of 5\% CLO-ST.

\begin{tabular}{|c|c|}
\hline Sensor-composition (W/W \%) & $\mathbf{. 5 \%} \mathbf{C L O}_{\mathbf{4}} \mathbf{S T , 5 4 \%}$ graphite, $\mathbf{4 1} \% \mathbf{2 - N P P E )}$ \\
\hline Slope (mV/decade) & $60.0 \pm 0.5$ \\
\hline Correlation coefficient $(r)$ & $60.0 \pm 0.5$ \\
\hline Limit of detection (M) & $3.5 \times 10^{-8}$ \\
\hline Linear range (M) & $1.0 \times 10^{-7}-1.0 \times 10^{-2}$ \\
\hline Working pH range & $1.2-4.8$ \\
\hline Response time (s) & $\leq 8$ \\
\hline Accuracy (\%) & $99.87 \pm 0.177$ \\
\hline Standard deviation (\%) & 0.326 \\
\hline Robustness & $99.79 \pm 0.23$ \\
\hline Ruggedness & $99.83 \pm 0.26$ \\
\hline
\end{tabular}

Table 3: Response characteristics of CLO-CMCPS at $95 \%$ confidence intervals at $25.0 \pm 0.1^{\circ} \mathrm{C}$.

\begin{tabular}{|c|c|c|c|c|c|}
\hline Interferent $^{\mathrm{b}}$ & MPMa & SSM & Interferent ${ }^{b}$ & MPM $^{\mathbf{a}}$ & SSM \\
\hline $\mathrm{K}^{+}$ & 2.88 & 3.15 & Cr3+ & 3.33 & 4.20 \\
\hline $\mathrm{Na}^{+}$ & 2.95 & 3.33 & Maltose & 3.52 & --- \\
\hline $\mathrm{NH}_{4}^{+}$ & 2.65 & 2.93 & Glucose & 3.50 & --- \\
\hline $\mathrm{Ba}^{2+}$ & 3.21 & 3.55 & Lactose & 3.54 & --- \\
\hline $\mathrm{Cu}^{2+}$ & 3.20 & 3.62 & Urea & 3.23 & --- \\
\hline $\mathrm{Co}^{2+}$ & 3.11 & 3.55 & Ascorbic acid & 3.30 & --- \\
\hline $\mathrm{Ni}^{2+}$ & 3.19 & 3.65 & Aspirin & 1.15 & --- \\
\hline $\mathrm{Mn}^{2+}$ & 2.56 & 3.11 & L-Lysine & 3.34 & --- \\
\hline $\mathrm{Mg}^{2+}$ & 2.89 & 3.36 & L-cystine & 3.20 & --- \\
\hline $\mathrm{Zn}^{2+}$ & 2.67 & 3.28 & L-Glycine & 3.19 & --- \\
\hline $\mathrm{Fe}^{3+}$ & 3.27 & 3.76 & L-Theronine & 3.44 & --- \\
\hline
\end{tabular}

(---): No response

aEach value is the average of three determinations.

${ }^{b}$ Allinterferents ions are in the form of chloride solution ( $0.5 \mathrm{M}$ for MPM) \& $\left(10^{-3} \mathrm{M}\right.$ for SSM).

Table 4: Selectivity coefficient values for $-\log \mathrm{K}_{\text {Drug, } \mathrm{J}^{2+}}^{\text {pot }}$ CLO-ST/CMCPS.

the sensor can be safely used for CLO determination. For quantitative measurements with ion selective sensors, studies were carried out to reach the optimum experimental conditions. Therefore, the $\mathrm{pH}$ range from 1.2 to 4.8 was assumed to be the working $\mathrm{pH}$ range of the sensors. It can be seen from Figure 4 that at $\mathrm{pH}$ values lower than the previously 


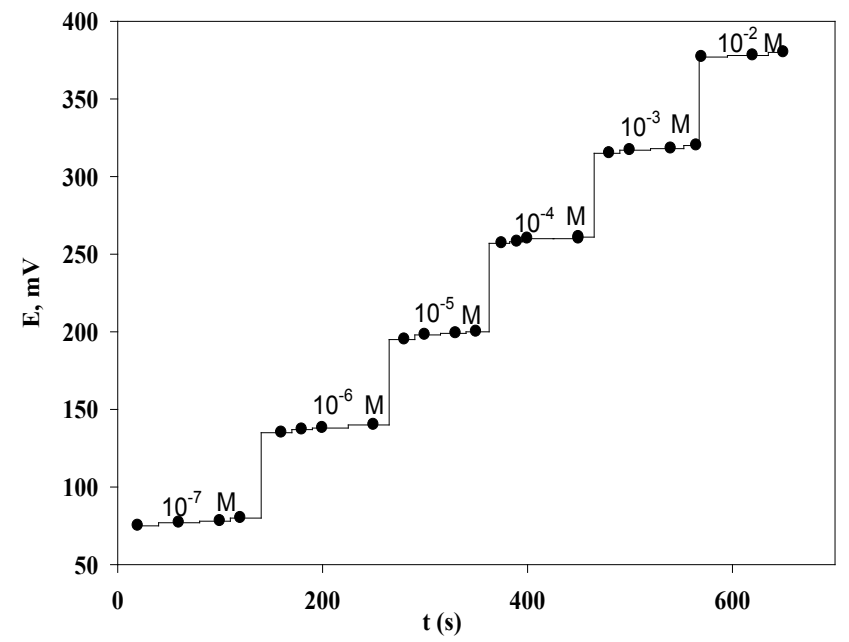

Figure 3: Potential-time plot for response of the CLO-ST/CMCP.

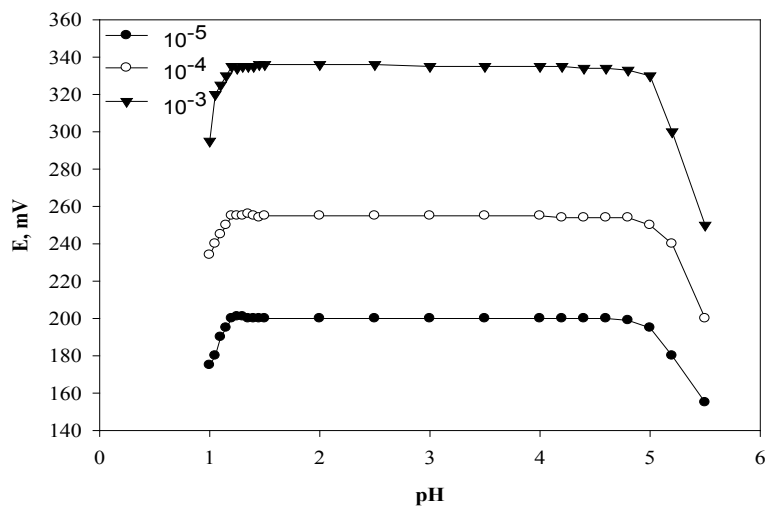

Figure 4: Effect of $\mathrm{pH}$ on the response of CLO-ST/CMCPS.

mentioned $\mathrm{pH}$ ranges, the potential readings increase which can be related to interference of hydronium ion while at $\mathrm{pH}$ values higher than $\mathrm{pH} 4.8$, the potential readings decrease gradually due to the formation of free base of the drug and decrease of the protonated species in the test solutions as shown in Figure 4.

\section{Effect of temperature}

Thermal stability of the sensor: To study the thermal stability of the sensors, calibration graphs (emf, $\mathrm{mV}$ vs. pDrug) were constructed at different test solution temperatures covering the range $25-50^{\circ} \mathrm{C}$. The results indicate that the slopes of the calibration graphs still in the Nernstian range in spite of the increase of the temperature of the test solutions up to $50^{\circ} \mathrm{C}$ as shown in Figure $5 \mathrm{a}$.

Determination of the thermal coefficient of the sensors: The potential of ion-selective sensors is usually affected by the temperature of the test solution. A thermally stable sensor is characterized by low thermal temperature coefficient. This means the successful applicability of the sensor over a wide range of temperature. To calculate the thermal coefficient of the cell $\left(\mathrm{dE}^{\circ} / \mathrm{dt}\right)_{\text {cell }}$, the standard cell potentials, $\mathrm{E}_{\text {cell }}^{\mathrm{o}}$, were determined at different temperatures from the respective calibration plots as the intercept of these plots at $\mathrm{p}$ Drug=0. Knowing that $\mathrm{E}_{\text {cell }}^{\circ}$ is related to $(\mathrm{dE} / \mathrm{dt})$ by the equation:

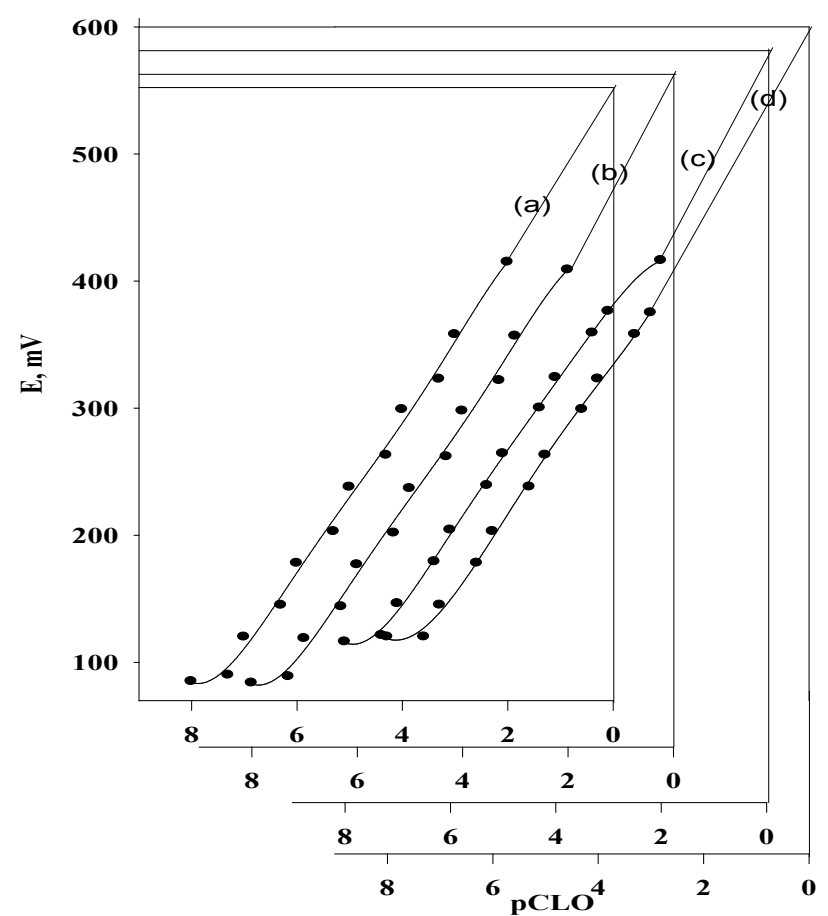

Figure 5a: Calibration graphs for CLO-ST/CMPS at the test solution temperatures $25^{\circ} \mathrm{C}(\mathrm{a}), 35^{\circ} \mathrm{C}(\mathrm{b}), 40^{\circ} \mathrm{C}(\mathrm{c})$ and $50^{\circ} \mathrm{C}(\mathrm{d})$.

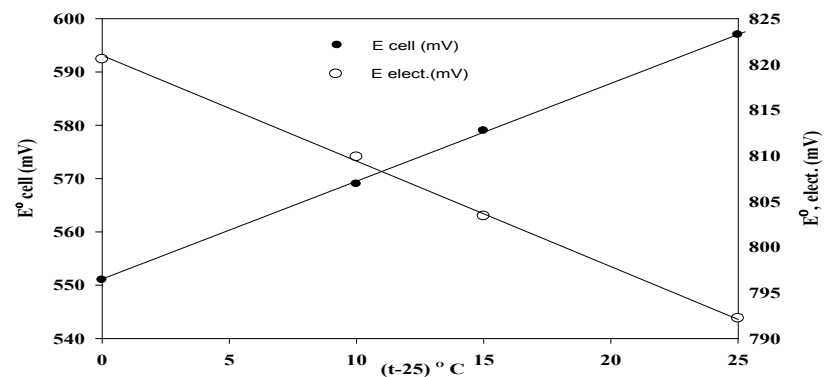

Figure 5b: Variation of standard electrode potential and standard potential of the cell containing CLO-ST/CMPS with changes of test solution temperatures.

$$
\mathrm{E}_{\text {cell }}^{\circ}=\mathrm{E}_{25 \mathrm{C}}^{\circ}+(\mathrm{dE} / \mathrm{dt})(\mathrm{t}-25)^{\circ} \mathrm{C}
$$

Plot of $\mathrm{E}_{\text {cell }}^{\mathrm{o}}$ versus $(\mathrm{t}-25)^{\circ} \mathrm{C}$ produced a straight line; the slope of this line is taken as the thermal coefficient of the cell, as shown in Figure $5 \mathrm{~b}$. The value of the standard potentials of sensor ( $\mathrm{E}^{\circ} \mathrm{elec}$.) was calculated after the subtraction of the standard sensor potential of the calomel sensor at different temperatures (the values are 241.2, 234.4, 230.88 and $223.57 \mathrm{mV}$ at $25,35,40$ and $50^{\circ} \mathrm{C}$, respectively). Plots of $\left(\mathrm{E}_{\text {elec }}^{\mathrm{o}}\right)$ versus $(\mathrm{t}-25)^{\circ} \mathrm{C}$ gave a straight line. The slope of the line was taken as the thermal coefficient of the sensor.

The isothermal coefficient $\left(\mathrm{dE}_{\text {elec. }} / \mathrm{dt}\right)$ of the sensor was calculated and found to be $\sim 0.0001 \mathrm{~V}^{\circ} \mathrm{C}^{-1}$ and $\left(\mathrm{dE}_{\text {cell }} / \mathrm{dt}\right)$ equals $\sim 0.0005 \mathrm{~V}^{\circ} \mathrm{C}^{-1}$. These values indicate a fairly high thermal stability of the sensor within the temperature range investigated and show no large deviation from the theoretical Nernstian behavior.

\section{Selectivity of the sensor}

The selectivity coefficients presented in Table 4 indicate that, CLO- 
Citation: Khorshid AF (2014) New Analysis of Clopidogrel Bisulphate in Plavix Tablet and Human Biological Fluids Utilizing Chemically Modified Carbon Paste Sensor. Pharm Anal Acta 5: 301. doi:10.4172/2153-2435.1000301

Page 6 of 9

\begin{tabular}{|c|c|c|c|c|c|c|c|}
\hline \multicolumn{3}{|c|}{ I- Standard addition method ${ }^{a}$} & \multicolumn{5}{|c|}{ III- Potentiometric titrations } \\
\hline \multirow[b]{2}{*}{ Taken (mg) } & \multirow[b]{2}{*}{ Recovery (\%) } & \multirow[b]{2}{*}{ R.S.D. \% } & \multicolumn{3}{|c|}{ Pure solutions } & \multicolumn{2}{|l|}{ Plavix tablets } \\
\hline & & & Taken (mg) & Recovery (\%) & R.S.D.\% & Recovery (\%) & R.S.D. \% \\
\hline \multicolumn{3}{|c|}{ Pure solutions } & \multicolumn{3}{|c|}{ STA as titrant } & & \\
\hline 2.1 & 99.1 & 0.63 & 6.3 & 99.6 & 0.50 & 98.5 & 0.65 \\
\hline 4.2 & 99.3 & 0.55 & 8.4 & 99.1 & 0.77 & 98.1 & 1.41 \\
\hline 6.3 & 99.0 & 0.81 & 12.6 & 99.0 & 0.89 & 98.0 & 1.08 \\
\hline 8.4 & 98.2 & 0.64 & 21.0 & 98.2 & 0.99 & 97.3 & 0.97 \\
\hline \multicolumn{3}{|c|}{ Plavix tablets } & \multicolumn{3}{|c|}{ PTA as titrant } & & \\
\hline 2.1 & 99.0 & 0.22 & 4.2 & 99.3 & 0.77 & 99.0 & 1.05 \\
\hline 4.2 & 98.9 & 0.48 & 12.6 & 98.7 & 0.59 & 98.6 & 1.04 \\
\hline 6.3 & 98.0 & 0.51 & 21.0 & 98.0 & 0.47 & 98.5 & 1.18 \\
\hline \multicolumn{3}{|c|}{ II- Calibration curve method } & 29.4 & 98.0 & 0.68 & 98.2 & 0.96 \\
\hline 6.3 & 99.3 & & 42.0 & 97.6 & 0.78 & 97.0 & 1.44 \\
\hline 8.4 & 98.6 & & \multicolumn{3}{|c|}{ SMA as titrant } & & \\
\hline 12.6 & 98.0 & & 2.1 & 99.7 & 0.44 & 99.0 & 0.85 \\
\hline \multicolumn{3}{|c|}{ Plavix tablets } & 4.2 & 99.3 & 0.67 & 99.4 & 0.64 \\
\hline 2.1 & 98.4 & & 6.3 & 99.0 & 0.78 & 98.6 & 0.84 \\
\hline 4.2 & 98.5 & & 8.4 & 98.5 & 0.51 & 98.0 & 0.77 \\
\hline 6.3 & 98.7 & & 12.6 & 98.3 & 0.73 & 98.2 & 1.11 \\
\hline \multicolumn{3}{|c|}{ Spiked urine $^{a}$} & 29.4 & 98.0 & 0.80 & 97.0 & 1.23 \\
\hline 2.1 & 99.0 & 0.21 & \multicolumn{3}{|c|}{ PMA as titrant } & & \\
\hline 4.2 & 98.6 & 0.24 & 4.2 & 99.8 & 0.16 & 99.5 & 0.84 \\
\hline 6.3 & 98.3 & 0.43 & 6.3 & 99.4 & 0.77 & 99.3 & 0.26 \\
\hline \multicolumn{3}{|c|}{ Spiked human serum ${ }^{a}$} & 8.4 & 99.0 & 0.78 & 99.1 & 0.65 \\
\hline 2.1 & 98.3 & 0.67 & 12.6 & 98.5 & 0.58 & 98.5 & 0.91 \\
\hline 4.2 & 98.0 & 0.48 & 29.4 & 98.0 & 0.88 & 98.0 & 0.38 \\
\hline 6.3 & 97.6 & 1.09 & 42.0 & 98.3 & 0.30 & 97.8 & 0.69 \\
\hline
\end{tabular}

Table 5: Determination of clopidogrel bisulfate in bulk solutions, tablet,urine and serum applying the standard addition method, calibration curve method and potentiometric titrations using CLO-ST/CMCPE.

\begin{tabular}{|c|c|c|c|c|c|c|}
\hline \multicolumn{4}{|c|}{ Pure solution } & \multicolumn{3}{|c|}{ Tablet } \\
\hline Method & $X \pm$ S.E. & Relative error (\%) & $\mathrm{F}^{3.3}$ value $(9.28)$ & $X \pm$ S.E. & Relative error (\%) & $\mathrm{F}^{3.3}$ value $(9.28)$ \\
\hline Official method [32] & $98.0 \pm 0.50$ & 0.851 & & $97.0 \pm 0.6$ & 0.90 & \\
\hline Method (I) & $99.2 \pm 0.11$ & 0.891 & 0.785 & $98.6 \pm 0.112$ & 0.621 & 0.566 \\
\hline Method (II) & $99.5 \pm 0.46$ & 0.624 & 0.748 & $98.9 \pm 0.013$ & 0.651 & 0.901 \\
\hline Method (III) & $99.7 \pm 0.06$ & 0.339 & 0.806 & $99.5 \pm 0.372$ & 0.917 & 0.739 \\
\hline \multicolumn{4}{|c|}{ Spiked urine } & \multicolumn{3}{|c|}{ Spiked human serum } \\
\hline Official method [32] & $98.0 \pm 0.44$ & 0.822 & & $98.1 \pm 0.2$ & 0.911 & \\
\hline Method (I) & $98.7 \pm 0.73$ & 0.621 & 0.625 & $98.5 \pm 0.035$ & 0.481 & 0.577 \\
\hline
\end{tabular}

Method (I): The standard addition method.

Method (II): The Calibration curve method.

Method (III): The Potentiometric titrations method.

$X \pm$ S.E: Recovery \pm standard error

F- tabulated is 6.39 at $95.0 \%$ confidence limit.

$\mathrm{t}$ - tabulated at $99.0 \%$ confidence limit and 6 degrees of freedom

Table 6: Statistical treatment of data obtained for the determination of CLOusing the CLO-ST/CMCPE.

ST sensor is highly selective to clopidogrel cation. Most inorganic cations do not interfere because of the difference in their mobility and permeability as compared to clopidogrel cation. In the case of sugars and amino acids the high selectivity is related to the difference in polarity and lipophilic nature of their molecules relative to clopidogrel cation.

\section{Quantification of CLO}

In order to assess the validity of the proposed sensor, the analytical applications involve determination of the drug in its bulk powder, pharmaceutical preparation (Plavix $75 \mathrm{mg}$ ) and biological fluids (serum \&urine) was applied. Applying the standard addition method [40], the percentage recovery for determinations of CLO in pure solution, Plavix
Tablets and in spiked urine and human serum ranged from 98.2-99.3\%, 98.0-99.0, 98.3-99.0 and 97.6-98.3 respectively, (Table 5).

While in Calibration curve method the percentage recovery for determinations of CLO in pure solution and Plavix Tablets are ranged from 98.0-99.4 and 98.3-98.7 respectively. The potentiometric titration technique usually offers the advantage of high accuracy and precision, a further advantage is that the potential break at the titration end-point must be well defined. The titration process was carried out manually in aqueous solution containing 4.20-42.0 mg CLO with average recoveries of 98.2-99.6\% using NaTPB as titrant, 97.3-98.5\% in Plavix tablets.

On using PTA as titrant, 97.6-99.3\%, 97.0-99.0\%, on using SMA as titrant, 98.0-99.7\%, 97.0-99.4, and on using PMA as titrant, 98.0-99.8\%, 
97.8-99.5\% for pure solution and Plavix tablets respectively, Figure 6. The results applying the potentiometric titration method Table 5. The results obtained were compared with those of official method [35]. No significant difference between two methods was observed with respect to accuracy and precision (Table 6).

\section{Validation of the proposed method}

Linearity and detection limit (LOD): Under the optimal experimental CMCPS conditions, a linear relationship exists between the sensor potential $/ \mathrm{mV}$ and the logarithm of corresponding concentration of the investigated drug, the value of LOD was indicating that the proposed method is sensitive for detection of very small concentrations of CLO reach to $0.35 \mathrm{nM}$. The correlation coefficient $(\mathrm{r})$ and other statistical parameters were listed in Table 3.

Accuracy: The accuracy of the proposed CMCPS method was investigated by the determination of CLO in its pharmaceutical preparations without interfering from the coformulated adjuvant as indicated by the mean recovery value of $99.87 \pm 0.177 \mathrm{mV} /$ decad for the investigated sensor.

Precision: The precision of the CMCPS method measured as percentage relative standard deviation (\% RDS) was tested by repeating the proposed CMCPS method for analysis of the investigated CLO in intra-day (within the day) and inter-day (consecutive days) to five replicates. The obtained \%RSD values were $0.379 \%, 0.466 \%$ for the sensor. The $\%$ RSD values are less than $2 \%$, indicating good precision.

\section{Analytical applications}

The standard addition method was proved to be successful for the determination of clopidogrel in its bulk solutions, Plavix tablet $(75 \mathrm{mg} /$ tablet) and biological fluids human serum/urine using its prepared chemically modified carbon paste sensor.

Determination of Plavix tablet (75 $\mathrm{mg} /$ tablet): In order to assess the validity of the proposed sensor, the standard additions method [40], calibration curve method and the potentiometric titration method (Table 5 and Figure 6) show the determination of CLO in its

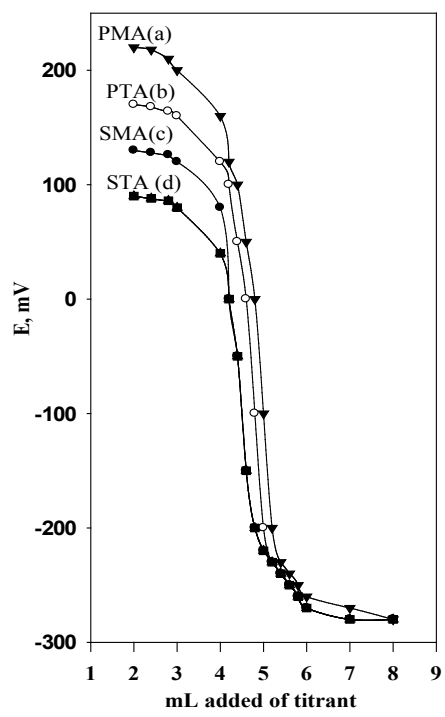

Figure 6: Potentiometric titrations of $21.0 \mathrm{mg} \mathrm{CLO}-\mathrm{H}_{2} \mathrm{SO}_{4}$ with PMA (a), PTA (b), SMA (c), and STA (d) as titrants using CLO-ST/CMCPS.

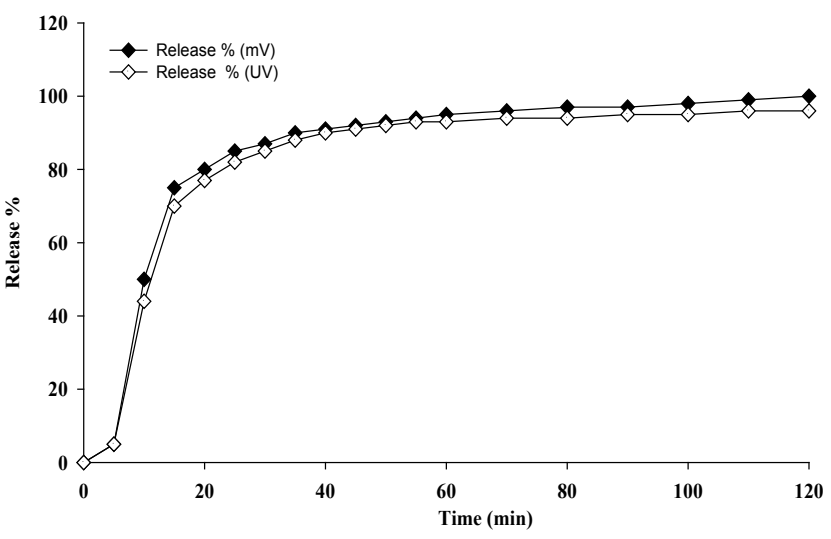

Figure 7: Dissolution of profiles of $75 \mathrm{mg}$ clopidogrel bisulfate tablet obtained by potentiometric: $5.0 \%$ CLO-CMPS, and spectrophotometric measurements at $240 \mathrm{~nm}$.

bulk solutions and tablet. The results also prove the applicability of the three methods for the determination of CLO in the pharmaceutical formulation.

Determination of CLO in (Human serum and urine): The proposed CMCPS method was successfully applied to determine CLO in biological fluids and the results obtained were summarized in Table 5. The determination of CLO in spiked human serum shows that a wide concentration range of the drug can be determined by the investigated sensor with high precision and accuracy. In urine samples the standard addition technique was applied to overcome the matrix effects in these samples. Also, the response times of the proposed sensors are instant (within $15 \mathrm{~s}$ ), so the sensors are rapidly transferred back and forth between the biological samples and the bi-distilled water between measurements to protect the sensing component from adhering to the surface of some matrix components. It is concluded that the proposed sensors can be successfully applied to in vitro studies and for clinical use. This confirms that the sensitivity and limit of quantification (LOQ) are adequate for determination of clopidogrel bisulfate in pharmacokinetic studies.

Potentiometric monitoring of Plavix tablet dissolution [35,36]: The dissolution test was operated at $50 \mathrm{rpm}$ in $900 \mathrm{ml} 1.0 \times 10^{-2}$ $\mathrm{M}$ hydrochloric acid (simulated duodenum fluid), and the use of potentiometric clopidogrel sensor. The simulated duodenum fluid was kept at $37.0 \pm 0.5^{\circ} \mathrm{C}$. There are no degradation products in the vitro test. The compression recipients do not interfere. Taking into account the S-shape of the dissolution curve obtained Figure 6. It shows that clopidogrel releases immediately after capsule was ruptured. More than $75 \%$ drug was released within $15 \mathrm{~min}$ and complete dissolution was achieved in $120 \mathrm{~min}$.

The potentiometric method, the potential values were continuously recorded at 1-min time intervals and compared with a calibration graph. For the UV spectrophotometric assay, fixed volumes of the dissolution medium were withdrawn, diluted with $0.01 \mathrm{M} \mathrm{HCl}$, measured at $\lambda \max 240 \mathrm{~nm}$ and compared with a calibration graph. Figure 7 shows the dissolution profiles of clopidogrel tablet using both measurement techniques. The results obtained by spectrophotometric and potentiometry are almost identical. The use of the potentiometric method sensor, however, has the advantage of in situ monitoring.

Robustness and ruggedness: The robustness method of the CLOCMCPS was examined by changed the aqueous solution to acetate 
Citation: Khorshid AF (2014) New Analysis of Clopidogrel Bisulphate in Plavix Tablet and Human Biological Fluids Utilizing Chemically Modified Carbon Paste Sensor. Pharm Anal Acta 5: 301. doi:10.4172/2153-2435.1000301

Page 8 of 9

\begin{tabular}{|c|c|c|c|c|c|c|}
\hline \multirow[t]{3}{*}{ ISS } & \multirow{3}{*}{\multicolumn{2}{|c|}{$\begin{array}{c}\text { Ref [33] } \\
\text { TpCIPB- (PVC) }\end{array}$}} & \multicolumn{4}{|c|}{ Ref [34] [C.S] } \\
\hline & & & (PMA) & (ARS) & \multicolumn{2}{|c|}{ (PTA) CMCPS } \\
\hline & & & \multicolumn{4}{|c|}{ (DBP) (2-NPPE) } \\
\hline Parameter & O-NPOE & DOP & Plastic & Coated-Ag & Coated-graphite & CLO-ST \\
\hline Slope (mV/decade) & 61.7 & 59.3 & 55.97 & 57.57 & $58.03 \pm 0.150$ & $60.0 \pm 0.5$ \\
\hline Correlation coefficient $(r)$ & 0.9874 & 0.9993 & 0.9998 & 0.9999 & 0.9999 & 0.9999 \\
\hline Linear range $(\mathrm{M})$ & - & -- & \multicolumn{3}{|c|}{$1 \times 10^{-7}-1 \times 10^{-2}$} & $1 \times 10^{-7}-1 \times 10^{-2}$ \\
\hline LOD (M) & \multicolumn{2}{|c|}{$1.0 \times 10^{-5}$} & $5.01 \times 10^{-8}$ & $4.1 \times 10^{-8}$ & $5.0 \times 10^{-8}$ & $3.5 \times 10^{-8}$ \\
\hline Working $\mathrm{pH}$ range & \multicolumn{2}{|c|}{$1.5-4.0$} & \multicolumn{3}{|c|}{$1.2-4.6$} & $1.2-4.8$ \\
\hline Response time (s) & & & 20 & 25 & 15 & $\leq 8$ \\
\hline Life span/days & 77 & 84 & 25 & 30 & 40 & Fresh surface \\
\hline Accuracy (\%) & -- & -- & $99.09 \pm 0.6$ & $99.72 \pm 0.24$ & $99.28 \pm 0.857$ & $99.87 \pm 0.177$ \\
\hline Standard deviation & -- & -- & 0.460 & 0.227 & 0.150 & 0.326 \\
\hline Robustness & & & $99.48 \pm 0.537$ & $99.36 \pm 0.337$ & $99.51 \pm 0.445$ & $99.79 \pm 0.23$ \\
\hline Ruggedness & & & $99.51 \pm 0.430$ & $99.26 \pm 0.650$ & $98.77 \pm 0.199$ & $99.83 \pm 0.26$ \\
\hline
\end{tabular}

Table 7: Comparison between some of the published and the suggested methods for determination of CLO-ion.

buffer $\mathrm{pH} 4 \pm 0.5$ and the percentage result was $99.79 \pm 0.23 \mathrm{mV} /$ decad for the CLO-ST.

This result was closely in agreement with those obtained from standard drug solution, (Table 1). While the ruggedness or the reproducibility was checked by using another model of $\mathrm{pH}$-meter (Jenway, 3505) was indicated by the results obtained as percentage was $99.83 \pm 0.26 \mathrm{mV} /$ decad for the same sensor Table 1 .

Content uniformity assay of Plavix tablets: The proposed ISE method described good accuracy and precision for the quality control tests, the content uniformity assay showed that accurate and reproducible results so the sensor can be employed for quantification of clopidogrel and the recovery of $\mathrm{CLO}-\mathrm{H}_{2} \mathrm{SO}_{4}$ is almost quantitative.

Statistical treatment of results: The results obtained from the potentiometric determination of the drug in these real samples are given in Table 5. The results of the recoveries of CLO applying the standard additions method, calibration curve method and the potentiometric titration were evaluated statistically and compared with the values obtained with the pharmacopeia method by applying the F-tests [43]. The values obtained Table 6 show that the present methods have a precision comparable to that of the pharmacopeia method. However, the proposed methods are more practical regarding time of analysis, consumption of solvents and sample pretreatment requirements for spectrophotometric or chromatographic analysis of clopidogrel bisulfate.

Comparison of the clopidogrel selective sensors: The performance characteristics of the proposed sensor and those of some reported ISE method are presented in Table 7 for comparison. It is clear that the proposed sensor CMCPS is comparable with most of the reported sensors with regard to working concentration range, response time and low detection limit. Overall evaluation indicates this sensor is more useful in such applications.

\section{Conclusion}

The proposed potentiometric methods based on the construction of different types of selective sensors with ion exchangers might be useful analytical characteristics for the determination of CLO in its bulk solutions, pharmaceutical dosage form and biological fluids. The good recoveries and low relative standard deviations obtained reflect the high accuracy and precision of the proposed method. Moreover, the method is simple, easy to operate, high sensitivity, reasonable selectivity, fast static response, long term stability and applicability over a wide concentration range with minimal sample pretreatment and inexpensive making it an excellent tool for the routine determination of CLO in quality control laboratories. The sensor developed is superior as compared with the clopidogrel selective sensor described in the literature $[33,34]$.

\section{Acknowledgements}

I gratefully acknowledge the support of National Organization for drug control and research (NODCAR) in Giza-Egypt, by the chemicals and dissolution equipment also acknowledge the supporting of Central Research Lab at Nahda University with the other equipments at the practical work.

\section{References}

1. Budavari S (2011) The Merck Index. (13thedn). Merck \& Co. Inc., 856-859.

2. Henein W (2006) ATLAS 2 everything about drugs from $A$ to $Z$. Nobar publisher, 282- 288.

3. Gomes Y, Adams E, Hoogmartens (2004) Analysis of purity in 19 drug product tablets containing clopidogrl: 18 copies versus the original brand. J Pharma Biomed Anal. 34: 341-348.

4. Taubert D, Kastrati A, Gorchakova O, Lazar A, Von Beckerath N, et al. (2004) Pharmacokinetics of clopidogrel after administration of a high loading dose. Thromb Haemost 92: 311-316.

5. YogitaShete NS, Mahajan YV, Pore RL, Kuchekar BS (2009) Spectrophotometric estimation of clopidogrel bisulphate in pharmaceutical. Int J Chem Sci $7: 216$ 218

6. Game MD, Gabhane KB, Sakarkar DM (2010) Quantitative analysis of clopidogrel bisulphate and aspirin by first derivative spectrophotometric method in tablets. Ind J Phama Sci 72 : 825-828.

7. Gurav S, Tembare R, Salunkhe V, Devprakash A, Senthilkumar GP (2011) Spectrophotometric determination of clopidogrel bisulphate in pharmaceutical formulations. J Pharma Tech Res 1: 258-263.

8. Cholke PB, Ahmed R, Chemate SZ, Jadhave KR (2012) Development and validation of spectrophotometric method for clopidogrel bisulphate in pure and in film coated tablet dosage form. Arch Appli Sci Res 4: 59-64.

9. Rujput SJ, George RK, Ruikar DB (2008) Chemometric simultaneous estimation of clopidogrel bisulphate and aspirin from combined dosage. Ind $J$ Pharma Sci 70: 450-454

10. El Yazbi FA, Mahrous ME, Hammad HH, Sonji GM, Soni NM (2010) Kinetic spectrophotometric determination of betaxolol, clopidogrel and imidapril in pharmaceutical. Anal Techn 6: 228-236.

11. Reist M, Roy-de Vos M, Montseny JP, Mayer JM, Carrupt PA, et al. (2000) Very slow chiral inversion of clopidogrel in rats: a pharmaceutical and mechanistic investigation. Drug Metab Dispos 28: 1405-1410. 
Citation: Khorshid AF (2014) New Analysis of Clopidogrel Bisulphate in Plavix Tablet and Human Biological Fluids Utilizing Chemically Modified Carbon Paste Sensor. Pharm Anal Acta 5: 301. doi:10.4172/2153-2435.1000301

12. Lagorce P, Pere $Y$, Ortiz J, Necciari J, Bressolle F (1998) Assay method for the carboxylic acid in human plasma by gas chromatography mass spectrometry. $J$ Chromatogr B Biomed Sci Appl 720: 107-117.

13. Shrivastava PK, Basniwal PK, Jain D, Shrivastava SK (2008) Concurrent estimation of clopidogrel bisulphate and aspirin in tablets by validated RP. HPLC method. Ind Pharma Sci 70: 667-669.

14. Alarfaj N (2010) Stability-indicating liquid chromatography for determination of clopidogrel bisulphate in tablets: Application to content uniformity testing. $J$ Saud Chem Soc 16: 23-30.

15. Panda SS (2010) lon-pairing RP-HPLC method for simultaneous determination of aspirin and clopidogrel bisulphate in tablet and capsule dosage form. Int $J$ Pharma Tech Res 2: 269-273.

16. Londhe SV, Deshmukh RS, Mulgund SV, Jain KS (2011) Development and Validation of a Reversed-phase HPLC Method for Simultaneous Determination of Aspirin, Atorvastatin Calcium and Clopidogrel Bisulphate in Capsules. Indian J Pharm Sci 73: 23-29.

17. Sultana N, Arayne MS, Ali KA, Nawaz M (2011) Simultaneous determination of clopidogrel and aspirin by RP-HPLC from bulk material and dosage formulations using multivariate calibration technique. J Chromatogr Sci 49: 165-169.

18. Patel RB, Shankar MB, Patel MR, Bhatt KK (2008) Simultaneous estimation of acetylsalicylic acid and clopidogrel bisulfate in pure powder and table formulations by high-performance column liquid chromatography and highperformance thin-layer chromatography. J AOAC Int 91: 750-755.

19. Sinha PK, Damel MC, Bothara KG (2009) A validated stability indicating HPTLC method for determination of aspirin and clopidogrel bisulphate in combined dosage form. J Anal Chem 4: 152-160.

20. Saber AL, Elmosallamy MA, Amin AA, Killa H (2007) Liquid chromatographic and potentiometric methods for determination of clopidogrel. J Food Drug Anal 16: $11-18$

21. Shu-qin L, Jian-wen L, Ji H, Xiao-fan S, Jin S, et al. (2008) Determination of the content of the compound clopidogrel bisulphate tablets by HPLC. J Shen Pharma Univ 25: 983-986.

22. Javed MK, Iqbal Z, Khan A, Shah Y, Ahmed L (2011) Development and validation of HPLC-UV method for the determination of clopidogrel in pharmaceutical dosage form and human plasma. J Liq Chromatogr Rela Techno 34: 2118-2129.

23. Shin BS, Yoo SD (2007) Determination of clopidogrel in human plasma by liquid chromatography/tandem mass spectrometry: application to a clinical pharmacokinetic study. Biomed Chromatogr 21: 883-889.

24. Takahashi M, Pang H, Kawabata K, Farid NA, Kurihara A (2008) Quantitative determination of clopidogrel active metabolite in human plasma by LC-MS/MS J Pharm Biomed Anal 48: 1219-1224.

25. Silvestro L, Gheorghe M, lordachescu A, Ciuca V, Tudoroniu A, et al. (2011) Development and validation of an HPLC-MS/MS method to quantify clopidogrel acyl glucuronide, clopidogrel acid metabolite, and clopidogrel in plasma samples avoiding analyte back-conversion. Anal Bioanal Chem 401: 10231034.

26. Fayed AS, Weshahy SA, Shehata MA, Hassan NY, Pauwels J, et al. (2009) Separation and determination of clopidogrel and its impurities by capillary electrophoresis. J Pharm Biomed Anal 49: 193-200

27. Karaźniewicz-Łada M, Główka F, Oszkinis G (2010) Capillary zone electrophoresis method for determination of (+)-S clopidogrel carboxylic acid metabolite in human plasma and urine designed for biopharmaceutic studies. $J$ Chromatogr B Analyt Technol Biomed Life Sci 878: 1013-1018.

28. Serra H, Bronze Mdo R, Simplício AL (2010) Simultaneous determination of clopidogrel and its carboxylic acid metabolite by capillary electrophoresis. $J$ Chromatogr B Analyt Technol Biomed Life Sci 878: 1480-1486.
29. Dermis S, Aydogan E (2010) Electrochemical study of the antiplatelet agent clopidogrel and its determination using differential pulse voltammetry in bulk form and pharmaceutical preparations with a glassy carbon sensor. Pharmazie 65: $175-181$

30. Moghaddam HM, Malakootian M, Beitollah H, Biparva P (2014) Nanostructured Base Electrochemical Sensor for Determination of Sulfite Int J Electrochem Sc 9: 327-341.

31. Švancara I, Vytřas K, Kalcher K, Walcarius A (2009) Review, Carbon Paste Sensors in Facts, Numbers, and Notes: A Review on the Occasion of the 50-Years Jubilee of Carbon Paste in Electrochemistry and Electroanalysis Electroanalysis J 21: 7-28.

32. Švancara I, Walcarius A, Kalcher K, Vytřas K (2009) Carbon paste sensors in the new millennium (Invited Review). Cent Eur J Chem 7: 598-656.

33. Saber AL, Elmosallamy MA, Amin AA, Killa HM (2008) Liquid Chromatographic and Potentiometric Methods for Determinations of Clopidogrel. J Food and Drug Analysis $16: 11-18$

34. Bin-Ibrahim SF, Alarfaj NA Aly FA (2012) Determination of Clopidogre bisulphate Using lon-Selective Sensors in Bulk. Pharmaceutical Formulation and in Biological Fluids. J American Science 8: 276-283.

35. United States Pharmacopeia (2009) National Formulary USP 32-NF 27 Convention, Inc. Rockville, MD.

36. Liddell M, Deng G, Hauck W, Brown W, Wahab S, Manning R (2007) Dissolution Technologies 14: 28

37. Khorshid AF, Issa YM (2014) Modified carbon paste sensor for the potentiometric determination of neostigmine bromide in pharmaceutical formulations, human plasma and urine. Biosensors and Bioelectronics 51: 143-149.

38. Umezawa Y, Buhlmann P, Umezawa K, Tohda K, Amemiya S (2000) Potentiometric selectivity coefficients of ion-selective sensors. Part I. Inorganic cations (technical report), Pure Appl Chem 72: 1851-1855.

39. Umezawa Y, Umezawa K, Sato H (1995) Selectivity coefficients for ion-selective sensors: recommended methods for reporting $\mathrm{K}_{\mathrm{A}, \mathrm{B}}{ }^{\text {pot }}$ values (technical report). Pure Appl Chem 67: 507-518.

40. Guilbault G, Drust RA, Frant MS, Freiser H, Hansen, et al. (1976) Recommendations for nomenclature of ion-selective sensors. Pure Appl Chem 48: 127-129.

41. Linder E, Umezawa $Y$ (2008) Performance evaluation criteria for preparation and measurement of macro- and micro fabricated ion-selective sensors. Pure Appl Chem 80: 85-104.

42. Skoog DA, Holler FJ, Neiman TA (1997) Principles of Instrumental Analysis. (5 edn). Harcourt Brace College Publishers, London.

43. Miller JC, Miller JN (1994) Statistics for Analytical Chemistry. Ellis Horwood Chichester, England 